\title{
BOREAS AND OREITHYIA ON A LATE ATTIC VASE.
}

\author{
[Plate VI.]
}

THE vase which is the subject of the present paper was acquired a few years ago in Italy for the Ashmolean Museum. The find spot was given as Capua.

The vase is a bell-krater, in height $20 \frac{5}{8} \mathrm{in.}(\mathrm{m} \cdot 523)$ in diameter $19 \frac{5}{8} \mathrm{in}$. (m 498). There is a wreath above, and a line of maeander pattern beneath the figures. The sides of the vase have a decoration of unusual richness. An elaborate pattern of palmettes rises to the handles, the roots of which are surrounded by the so-called egg-moulding (Eierstab). The reverse type is one of the conventional groups usual in this class of vases. Three youths, their long hair bound with wreaths (white), and wrapped in himatia, are standing together in a building which is indicated by a column rising in the midst. In the back-ground are hung up two square frames (dedications?); two tall curved leaves like notes of interrogation rise from the ground. One of the youths, to r., holds a patera; another, to 1., holds a strigil; the third is wrapped wholly in his cloak. In the field to $l$. is a flower.

The interest of the vase resides wholly in the painting of the obverse, which I take to be a new and probably unique representation of the carrying off of Oreithyia by Boreas. Boreas, who is represented as a dignified bearded man, clad in Phrygian cap, chiton with sleeves, chlamys and boots, is seizing by hair and right arm Oreithyia, who has flung herself violently on the ground, and raises her hands beseechingly to a richly draped matronly figure who is seated on a rock (hair in kerchief, under-and over-garment). An Eros, in a curious attitude, as if he were also perched on a rock rather than floating, rises beside the seated matron, holding some white object (wreath or fillet?) in both hands. Behind the matron stands a female figure, her hair bound with a sphendone, holding in her left hand the end of her veil. Behind Boreas, his horse advances to $r$. The drawing is very good for the period, which I take to be not very late in the fourth century. White colour is used for the face, arms and feet of the standing woman, the border of the cap of Boreas, and the mane of the horse, as well as for ornaments and accessories. Plate VI. is from a very faithful drawing, made by Mr. F. Anderson.

That the vase is Attic will probably not be disputed. The subject in itself points clearly to Athens. The elaborate devices under the handles, which are 


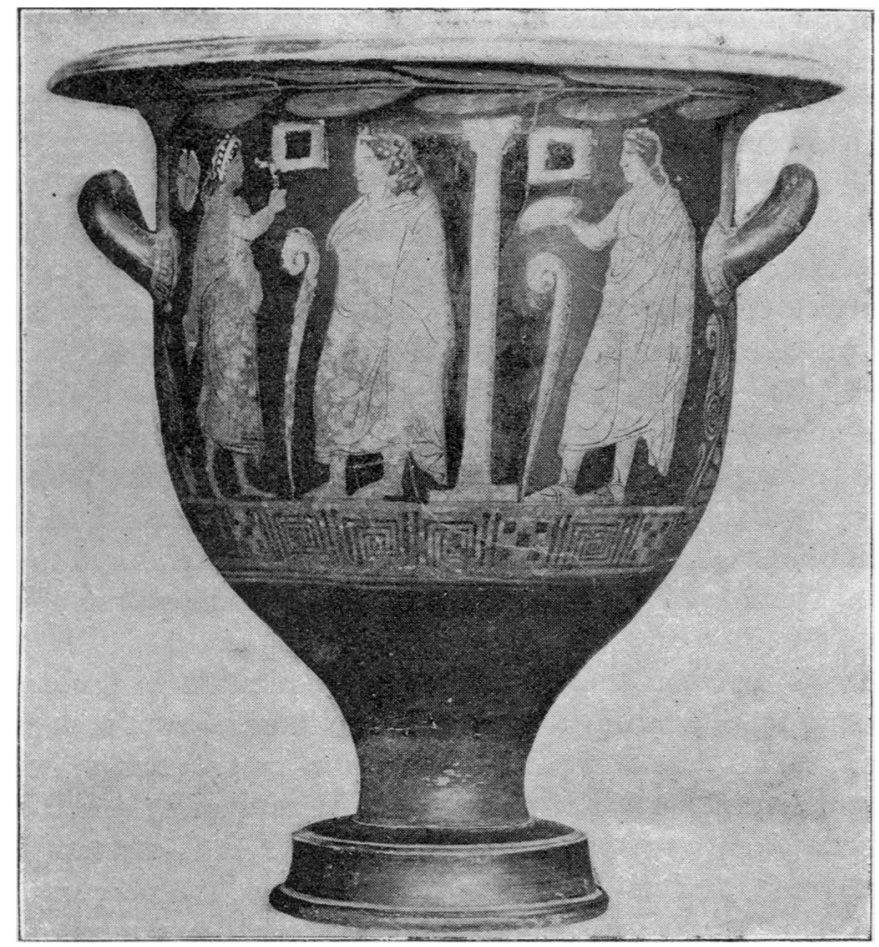

Krater in Ashmolean Museum (Reverse).

almost identical with those on an Attic vase of earlier style from Gela, recently acquired by the Ashmolean Museum, indicate the same origin. Vases of this class are in the Berlin Catalogue (Nos. 2641-8) and in the British Museum Catalogue (vol. iv) assigned to Athens.

Representations of the carrying off of Oreithyia by Boreas are by no means rare in Greek vase-painting. They are especially common on Attic vases of the fifth century. Sometimes the scheme is one of flight and pursuit : sometimes the girl is represented in the arms of her suitor. On the chest of Cypselus Boreas has the serpent legs of Typhon; on a red-figured vase $^{1}$ he is double-headed like Janus; Oreithyia like Thetis is often seized in the presence of her companions, who hasten away to tell the tale. The most important vase of this class is at Munich. ${ }^{2}$ It is a fine red-figured vase.

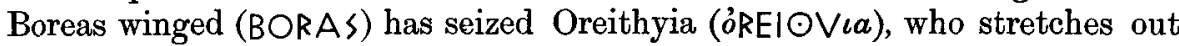
her hands towards Herse ( $\left.{ }^{\prime} P \leq E\right)$ who follows the pair with arms outstretched as if to aid: Pandrosos, Aglauros, and a third young woman not named, fly in terror to Cecrops and Erechtheus to tell them what has happened. A very similar vase at Berlin is published by Gerhard, 3 where the same figures

1 Ann. d. Inst. 32 (1860), Pl. L.M.

2 O. Jahn's Catalogue, No. 376. cf. Welcker, Alte Denkmäler, iii. p. 144.
3 Etrusk. u. Kampan. Vasenb. P1. 26-29. cf. Berlin Catalogue of Vases, No. 2165. 
reappear, though only the names of Boreas and Oreithyia are given; and where again Herse seems disposed to attempt a rescue. On one redfigured vase Athena is present, and is by no means out of place, since according to one version of the myth Oreithyia was carried off while engaged as a canephoros in her service. But according to more generally received accounts she was surprised while picking flowers by the Ilissus, or filling a vessel at Callirhoe, or carried off from the rocks of the Areiopagus.

A distinctive representation dating from the fourth century is found in the well-known akroterion of Delos. Here, Boreas, winged, clad only in drapery which falls behind the shoulders, and in boots, raises aloft Oreithyia, whom he has seized in the presence of two of her sisters or friends. ${ }^{1}$ At the feet of captor and captive, a small horse springs to the right. This horse, or mare, is taken by Miss Harrison to represent a transformation of Oreithyia, whom she thinks to have been, in origin, a sea-nymph, and so to have possessed, like Thetis and the Old Man of the Sea, the power of assuming various shapes.

In Roscher's Lexikon, under Boreas, p. 811, citation is made of a vase whereon a young man, wearing a Phrygian cap, bears away, in a quadriga, a struggling girl. This vase was published originally by Welcker, ${ }^{2}$ who took it for an abnormal representation of the carrying off of Oreithyia, and the writer in the Lexikon (Rapp) accepts the attribution. But it cannot be upheld; Stephani observes ${ }^{3}$ that all save the horses is modern painting, and the figures in the chariot have neither a genuine appearance, nor any likeness to Boreas and his bride. Probably, the real subject of the vase, which is of the Panathenaic class, is a victorious racing chariot.

Passing from other representations of the wooing of Boreas to our vase, we are struck by the many points in which it varies from the accepted version. To begin with, Boreas is not winged. The pattern on his cap and the scales on his sleeves serve to mark his northern origin, and his affinity to Scythians and Amazons. He wears tall hunting boots closely like those in the Delian group. The horse which accompanies him seems clearly meant to bear away the captive, and does not lend itself readily to the view of Miss Harrison above quoted, that it belongs rather to Oreithyia than to her suitor.

Of the three figures on the left of the picture one is undoubtedly Eros, and one must almost certainly be taken for Aphrodite. But it is possible to hesitate whether Aphrodite is the seated or the standing figure. We have, indeed, here, an interesting problem. Three views deserve consideration:-

(1) That the standing figure is Aphrodite, the seated figure a relative of Oreithyia.

(2) That the standing figure is Aphrodite, the seated figure an impersonation of locality.

(3) That the standing figure is Peitho, the seated figure Aphrodite.

\footnotetext{
1 See Furtwängler's restoration in Arch. Zeitung, 40, 339, Roscher's Lexikon, p. 813, Miss

The presence of the horse is a certainty. Harrison, Mythology and Monuments, p. loxvii.

2 Alte Denkmäler, v. pl. 21.

3 Boreas, p. 11.
} 
We must consider these possible interpretations in turn; and first, the view that the seated lady is related to Oreithyia.

The name of the wife of Erechtheus, Praxithea, is recorded, but according to all accounts, she was not present at the scene of abduction. We may, perhaps, suppose that the idea of separation from home has introduced the mother into the scene as the representative of home.

Greek vase paintings of all ages have, as every one knows, a strong tendency to fall under definite schemes, and the presence of a mother at a scene of abduction certainly adds a touch of pathos. Instances of the addition in vase-paintings of persons whose presence is rather ideal than actual are very common. We may cite, on black-figured vases, the father and mother of the Cercopes witnessing the capture of their sons, ${ }^{1}$ and Peleus and Neoptolemus present at the arming of Achilles ${ }^{2}$; on red-figured vases, Timandra present at the abduction of Helen, on the vase of Hieron; Apollo present at the duel of Achilles and Hector, ${ }^{3}$ and Cheiron present at the surprise of Thetis. Such instances might be multiplied, but it is unnecessary. Perhaps it is more to the point to observe that Demeter is sometimes, on vases, present at the seizing of Persephone, ${ }^{4}$ although, according to the received legend, she was absent at the time, and unaware, for a while, what had happened. It is true that the majority of archaeologists, from Millingen to Overbeck, have seen, in the vase paintings mentioned, not the first violent abduction of Cora, but her more peaceful annual departure to the world of shades; but this interpretation is doubtful, and even if it be adopted, Demeter should scarcely be present. An objection to the identification of our seated lady as Praxithea is that she is perfectly quiet and self-contained, evidently in no wise disturbed by the terror and the appeal of the girl.

Of one of the sisters or companions of Oreithyia we can scarcely think. Herse, daughter of Cecrops, is, as we have seen, present at the deed on some early vases, and even tries to interfere. But our seated lady can scarcely be Herse, nor can she be Athena, since none of the characteristic features of Athena appear.

A second interpretation is to find in the seated lady some personification of locality, perhaps Callirhoe, present, as Eleusis is sometimes present at the sending out of Triptolemus. The rock-seat would, certainly, very well suit this interpretation. On late vases, and especially in Pompeian paintings, such personifications are frequent in mythological scenes. And they take an interest in what is going forward, expressing sympathy by attitude and gesture. But they do not usually take an actual part in the action. It is difficult to think that Oreithyia could appeal for protection to Callirhoe, or any impersonation of locality.

The third interpretation remains, that the seated lady may be Aphrodite, and the standing figure behind her Peitho. In favour of this view is the

I Ashmolean Vases, Pl. 8.

2 Heydemann, Griech. Vasenbilder, vi. 4.

3 Gerhard, Auserl. Vasenb. 202.
4 Overbeck, Kunstmythol. pl. xvii., 26, 26a, cf. text, p. 597 . 
position of Eros, close to the seated figure. But an argument against it may be drawn from the attitude of Oreithyia, who is evidently appealing with vehemence to the seated figure. Aphrodite, if present, would be invisibly present; and an appeal to her would scarcely be in place.

Since there lie such serious objections to all interpretations which most readily occur, I am greatly disposed to adopt one which is more far-fetched, and has, as far as I know, no support from ancient writers, but yet has something in its favour. Can the seated figure be Gaia? Gaia was, in a sense, the mother of Erichthonius, who is scarcely to be distinguished from Erechtheus, and appears in vases at his birth. She is closely connected with the early dynasty of Attica. The figure on our vase, in its dignity, would stand well for Gaia. Her rock-seat is appropriate. And Gaia, knowing the future well, might probably regard with complaisance a deed of violence of which the results were so auspicious to the Athenians, who more than once during the Persian wars had cause to rejoice that Boreas was their son-in-law. On the other hand, it would be very natural for Oreithyia to make appeal to her ancestress, Gaia, if she were present.

I am quite alive to the dangers of giving far-fetched or fanciful interpretations of vase scenes, which in ninety-nine cases out of a hundred fall into classes and schemes. But, occasionally, a vase of unusual character makes its appearance, in interpreting which one is at liberty to assume more originality and more definite purpose in the painter. Our vase seems to me to belong to this small class. In any case, whatever the true interpretation of the picture before us may be, it is certainly a rare and important representation of an interesting Attic myth.

Percy Gardner. 


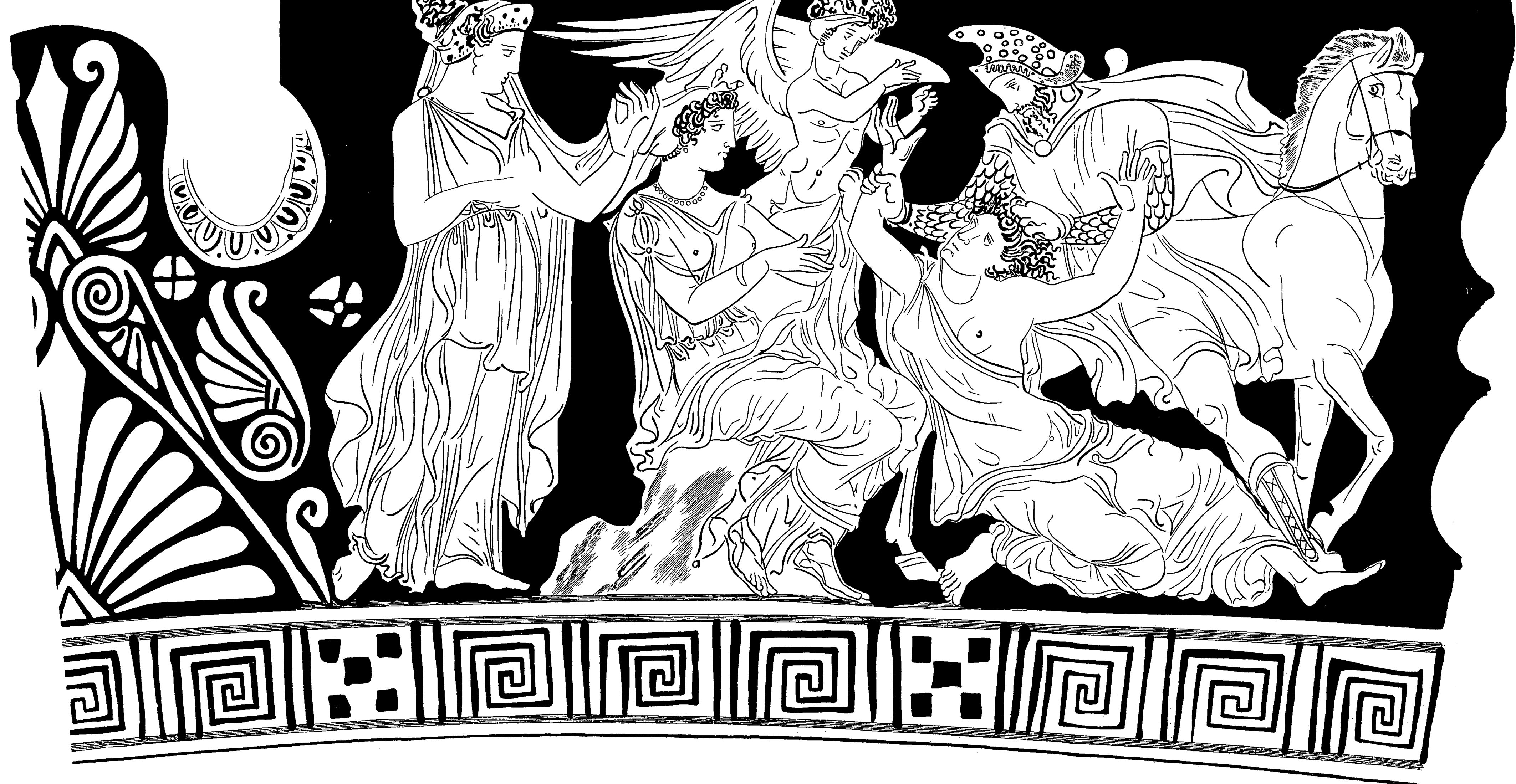

